\title{
Supremasi Hukum Pidana di Indonesia
}

\author{
Bunyana Sholihin \\ IAIN Raden Intan Lampung \\ bunyana_sol@yahoo.com
}

Supremacy of law has been an ideal for the Rechsstaat, such as Indonesia, in the sense that law is enforced and effective over every thing. Based on sociology of law theory, law could be enforced and effective in a national community if it conformed the legal spirit of the relevant nation. Ideally, therefore, for the supremacy of law, the criminal laws of Indonesia are those in conformity with the spirit of truth and justice trusted and embraced by Indonesian nation, because such laws are the only ones reflecting the spirit of Indonesian nation.

Keywords: supremacy of law, Indonesia, criminal law, spirit

\section{Pendahuluan}

A turan hukum pidana yang berlaku di In donesia hingga saat ini masih merupakan aturan hukum pidana peninggalan kolonial Belanda yang secara substansial hukum adalah aturan hukum penjajah untuk bangsa yang terjajah. Karena aturan hukum pidana yang berlaku di Indonesia hingga saat ini merupakan adopsi dari aturan pidana peninggalan kolonial Belanda dalam bentuk perundang-undangan pidana hasil terjemahan dari aturan hukum pidana yang termuat dalam kitab "Wetboek van Strafrecht voor Nederlandsch Indie 1915" dengan perbaikan dan penyesuaian di sanasini. Berdasarkan firman raja Belanda (Invoerings-verordening) tanggal 4 Mei 1917 (Stb. 1917 nomor 497) aturan pidana dimaksud secara khusus telah diberlakukan oleh pemerintahan kolonial Belanda terhadap bangsa jajahannya di nusantara sejak 1 Januari 1918. Sedangkan aturan pidana yang diberlakukan oleh pemerintahan Belanda untuk bangsanya sendiri adalah aturan pidana yang disusun untuk bangsa Belanda yang merdeka termuat dalam kitab
"Wetboek van Strafrecht 1881".

Mengingat suatu teori prinsip sosiologi hukum bahwa suatu aturan hukum akan dapat berjalan tegak, diterima dan dianut serta dijunjung oleh suatu masyarakat apabila hukum yang berlaku sesuai dengan jiwa dan semangat hukum masyarakat yang bersangkutan. Agar suatu aturan pidana yang diberlakukan di Indonesia lebih efektif dapat mewujudkan misi dan tujuan hukum itu sendiri maka idealnya hukum pidana yang berlaku di Indonesia adalah hukum yang sesuai dengan jiwa dan semangat hukum bangsa Indonesia. Sebagai realita sekarang Bangsa Indonesia adalah bangsa yang merdeka, berjiwa hukum dan semangat keadilan hukum tertentu. Secara fakta, mayoritas bangsa Indonesia terdiri dari masyarakat muslim beraliran hukum Syâfi'iyah.

Dari itu semua maka yang menjadi permasalahan dalam kajian ini adalah: Mungkinkah suprimasi hukum pidana dapat berjalan tegak dan dijunjung oleh masyarakat bangsa Indonesia yang merdeka dengan tetap mempertahankan berlakunya aturan pidana peninggalan kolonial Belanda di In- 
Supremasi Hukum Pidana di Indonesia; Bunyana Sholihin

donesia? Untuk menjawab permasalahan ini semua berikut perlu diadakan kajian khusus mengenai Hukum Pidana yang berlaku di Indonesia dan seluk-beluknya.

Kajian tentang Hukum Pidana dalam kaitannya dengan Supremasi hukum di Indonesia tidak lepas dari uraian mengenai seluk-beluk Hukum Pidana yang berlaku atau pernah berlaku dan mungkin berlaku sebagai acuan bertidak dan berbuat bagi bangsa Indonesia, Baik secara substansi material hukum (material law) maupun budaya hukumnya (cultural law). Oleh karena itu sifat penelitian ini adalah Penelitian Normatif yang akan mengurai seluk-beluk Hukum Pidana yang berlaku di Indonesia sehingga layak untuk diberlakukan, dianut dan dijunjung serta dapat menjamin tegaknya supremasi hukum pidana di Indonesia, dengan merujuk kepada sumber-sumber kepustakaan dengan menggunakan pendekatan sejarah sosial.

Selanjutnya data mengenai Hukum Pidana dan masyarakat sebagai subyek dan obyek hukumnya akan dianalisa dengan teknik analisis komparatif, yaitu analisis perbandingan antar masing-masing prinsip Hukum Pidana yang pernah dan mungkin berlaku di Indonesia sehingga dapat ditawarkan kesimpulan yang menjawab permasalahan.

\section{Kajian Pustaka}

Untuk menyajikan eksistensi Hukum Pidana Indonesia secara objektif dan komprehenship, maka dalam uraian berikut ini akan disajikan terlebih dahulu pengertian hukum pidana dan selanjutnya diikuti pula dengan uraian tentang sejarah hukum pidana di Indonesia. Sebelum lebih jauh membahas seluk beluk Hukum pidana di Indonesia perlu disampaikan terlebih dahulu pengertian Supremasi hukum sebagai idealitas dalam pengendalian suatu masyarakat bangsa.

\section{Pengertian Supremasi Hukum}

Kata"supremasi" itu sendiri secara bahasa adalah kata benda abstrak, berasal dari istilah Inggris supremacy yang diambil dari kata sifat supreme (tertinggi) yang seutuhnya berarti "keunggulan". Sedangkan istilah "Hukum" adalah salah-satu perangkat institusi pemenuhan kebutuhan rasa keadilan individu dalam suatu masyarakat. Dengan demikian dapat ditegaskan di sini bahwa "Supremasi Hukum" secara istilah berarti pengutamaan hukum di atas segalanya, yaitu meletakkan hukum di atas kedudukan, jabatan, kekayaan dan segalanya. Sehingga tertutup kemungkinan praktik hukum dikendalikan dan diatur oleh kedudukan, jabatan, harta kekayaan dan uang, tetapi hukumlah yang mengendalikan dan mengatur kedudukan, jabatan harta kekayaan dan uang untuk tegaknya keadilan yang menjadi cita-cita negara.

Supremasi hukum dalam pengertian istilah ini, sangat erat kaitannya dengan upaya praktek penerapan dan penegakan hukum (law inforcement) dalam kehidupan masyarakat, sehingga fungsi hukum dapat berdiri tegak menjalankan perannya menegakkan keadilan dalam kehidupan masyarakat khususnya di Indonesia.

\section{Pengertian hukum pidana}

Menurut bahasa, kata hukum pidana adalah terjemahan dari istilah Belanda strafrecht yang berasal dari gabungan kata straf yang berarti hukuman dan kata recht yang berarti hukum. Dengan demikian strafrecht secara bahasa berarti hukum hukuman. Terjemahan ini mengandung kerancuan arti, sehingga menurut Wirjono Prodjodikoro, kata hukuman lebih tepat kalau digantikan dengan kata pidana sehingga arti kesatuannya menjadi hukum pidana. Untuk lebih jelasnya perlu ditegaskan bahwa kata 
UNISIA, Vol. XXXI No. 69 September 2008

hukum itu adalah ungkapan bahasa Indonesia yang berasal dari bahasa Arab sebagai sumber bahasa agama yang dianut oleh mayoritas bangsaa Indonesia, yaitu Çáíßã yang berarti peraturan yang dibuat oleh suatu kekuasaan atau adat yang dianggap berlaku oleh dan untuk orang banyak. Sedangkan kata pidana berasal dari bahasa Sanskerta sebagai bahasa sastra agama Hindu yang telah berkembang di Nusantara sebelum agama Islam, yang berarti perbuatan-perbuatan kejahatan dan pelanggaran. Sedangkan setiap kejahatan dan pelanggaran itu beresiko hukuman. Dengan demikian secara bahasa pengertian hukum pidana sudah dapat difahami, yaitu: peraturan-peraturan mengenai kejahatan dan pelanggaran beserta sanksinya.

Namun demikian, menurut Wirjono yang lebih penting adalah pengertian hukum pidana dalam pengertian istilah hukum. Dalam pengertian istilah hukum ini banyak didapatkan batasan pengertian mengenai hukum pidana, antara lain:

Menurut Wirjono Prodjodokoro bahwa hukum pidana adalah peraturan-peraturan mengenai pidana. Batasannya itu diperjelas lagi dalam uraian berikutnya, bahwa hukum pidana adalah hukum yang memuat normanorma berupa larangan dan suruhan yang disertai ancaman hukuman atas pelanggarnya.

Menurut Soedarto, hukum pidana itu memuat aturan-aturan hukum yang mengikat kepada perbuatan-perbuatan yang memenuhi syarat tertentu untuk dijadikan suatu akibat yang berupa pidana.

Ridwan Halim memberikan batasan bahwa hukum pidana ialah hukum yang mengatur tentang perbuatan-perbuatan yang dilarang oleh undang-undang serta ancaman hukuman yang dapat dijatuhkan terhadap pelanggarnya.
Berdasarkan ketiga batasan pengertian hukum pidana menurut tiga pakar hukum tersebut, maka dapat dijelaskan bahwa hukum pidana itu memuat dua hal aturan sebagai berikut:

\begin{abstract}
Aturan hukum yang melukiskan perbuatan-perbuatan orang yang diancam pidana, artinya syarat-syarat yang harus dipenuhi sehingga memungkinkan pengadilan menjatuhkan pidana bagi pelakunya. $D i$ sini seolah-olah negara menyatakan kepada umum dan para penegak hukum mengenai perbuatan terlarang dan pelakunya yang dapat dipidana.
\end{abstract}

Aturan-aturan yang mengumumkan reaksi yang akan diterima oleh pelaku perbuatan terlarang. Dalam hukum pidana modern reaksi ini berupa pidana dan tindakan yang arif untuk melindungi masyarakat banyak dari perbuatanperbuatan yang merugikan.

Dari itu semua, maka hukum pidana itu adalah aturan-aturan hukum mengenai perbuatan-perbuatan yang diancam hukuman karena mengganggu prinsipprinsip kehidupan individu atau masyarakat.

\section{Sejarah hukum pidana di Indonesia}

Sebagaimana telah dikemukakan pada Bab Pendahuluan, bahwa Hukum Pidana Indonesia yang berlaku sekarang adalah hukum pidana peninggalan kolonial, berupa terjemahan dari Wetboek van Strafrecht voor Nederlandsch-Indie 1915. Adapun sejarah hukum pidana bagi bangsa Indonesia perlu dikemukakan secara tahapan kronologis perjalanan sejarah bangsa, yaitu dimulai hukum pidana sebelum zaman penjajahan, selanjutnya hukum pidana pada masa penjajahan Belanda, lantas hukum pidana pada masa pendudukan Jepang, 
Supremasi Hukum Pidana di Indonesia; Bunyana Sholihin

kemudian hukum pidana pada masa Republik seperti dibawah ini.

\section{a. Tahapan sebelum zaman penjajahan}

Di nusantara pada masa sebelum zaman penjajahan, yaitu sebelum Belanda masuk menguasai kerajaan-kerajaan di nusantara, banyak data yang menguatkan bahwa telah berlaku norma-norma kepidanaan berupa norma pidana adat. Norma pidana adat itu berlaku secara terpisah menurut wilayah kekuasaan setiap kerajaan. Diantaranya ada yang tertulis dan ada pula yang tidak tertulis. Dengan kata lain ada kerajaan yang telah membukukan dan memberlakukan norma pidana yang secara turun-temurun telah berlaku dan diakui pada setiap angkatan generasi suatu masyarakat, dan ada pula kerajaan yang hanya memberlakukan dan menerapkan norma-norma pidana yang berlaku dan diakui oleh sekelompok masyarakat secara turun-temurun untuk setiap kasus kejahatan atau pelanggaran.

Beberapa data yang menguatkan telah berlakunya norma pidana adat sebelum masuknya penjajahan Belanda di nusantara, antara lain:

1) Belum lama berselang, di beberapa daerah negara kesatuan Republik Indonesia masih ada apa yang dinamakan Peradilan Adat yang dijalankan oleh penguasa-penguasa daerah yang masih memberlakukan Hukum Pidana Adat. Pengadilanpengadilan Adat ini mempunyai nama yang menunjukkan keistimewaan khas setiap daerah, misalnya di Palembang disebut Rapat, di Bali disebut RadKerta, di Lombok disebut Rad-Sasak dan di Garontalo disebut Majlis.

2) Diketemukannya di pulau Bali suatu Kitab Perundang-Undangan Mojopahit yang tertulis dalam bahasa Jawa kuno. Kitab ini telah diterbitkan dalam bahasa Indonesia oleh Prof. Dr. Slamet Muljono. Di dalamnya termuat sejumlah pasal mengenai pidana dan sejumlah pasal lainnya mengenai keperdataan.

3) Di kalangan masyarakat adat Lampung dikenal kitab perundangundangan yang disebut Kitab Kuntara Adat Lampung. Kitab tersebut sampai sekarang masih dalam bentuk manuskrip yang tertulis dalam tulisan Aksara Lampung. Kitab tersebut di samping memuat aturan norma pemerintahan adat, pandangan hidup masyarakat adat, juga memuat norma aturan keperdataan dan kepidanaan.

Semua ini merupakan bukti sejarah bahwa bangsa Indonesia sejak lama telah mengenal aturan hukum, termasuk aturan hukum pidana.

\section{b. Tahapan zaman kolonial Belanda}

Sejak masuknya bangsa Belanda dan tata-hukumnya di nusantara tahun 1596 berlakulah dualisme hukum di Indonesia, yaitu di samping berlakunya Hukum Belanda Kuno yang berazaskan hukum Romawi yang dibawa masuk ke nusantara bersama kapal dagang Belanda pertama di bawah pimpinan Cornelis de Houtman yang disebut juga Hukum Kapal, di wilayah-wilayah nusantara secara turuntemurun telah berlaku aturan Hukum Adat masing-masing komunitasnya. Jadi dengan masuknya Hukum Kapal Belanda dan diberlakukan di bandar-bandar perdagangan nusantara, bagi bangsa Indonesia berlaku atasnya dua tatanan hukum, yaitu Hukum Kapal Belanda dan Hukum Adat. Hukum Kapal ini berlaku terus sampai beberapa tahun setelah berdirinya V.O.C (Verinigde Of Indische Compagne) tahun 1602. 
UNISIA, Vol. XXXI No. 69 September 2008

Lambat laun Hukum Kapal itu dirasakan tidak mampu lagi menyelesaikan masalahmasalah hukum yang terjadi di sejumlah bandar perdagangan di nusantara, sehingga dirasakan perlu adanya aturan hukum baru yang mampu mengatasi perkembangan masalah hukum di daerah-daerah yang dikuasai oleh V.O.C. Maka pada tahun 1609 Staten General (Badan Federasi Tertinggi) di negeri Belanda memberikan kekuasaan untuk menciptakan sendiri peraturan kepada pengurus V.O.C. di Banten. Oleh karena itu di daerah yang dikuasai V.O.C. dibuat dan diberlakukan peraturan hukum untuk penyelesaian perkara tertentu di masingmasing daerah perdagangan yang dikuasai V.O.C. Di samping itu pimpinan Heeren Zeventien (tujuh Belas Penguasa) di negeri Belanda juga menetapkan peraturanperaturan untuk diberlakukannya di daerah kewenangan V.O.C. Semua peraturan, baik yang dibuat oleh pengurus pusat V.O.C di Banten maupun yang dibuat oleh pimpinan Heeren Zeventien di negeri Belanda itu dimuat dalam papan pengumuman yang ditempelkan pada dinding kantor V.O.C., sehingga kemudian disebut Pelakat.

Selanjutnya setelah Pelakat disusun dan disempurnakan serta dihimpun dalam satu buku pada tahun 1642 oleh Mr. Joan Maetsyucker pejabat Hof van Justitie di Batavia dan mendapat pengesahan dari Heeren Zeventein di negeri Belanda pada tahun 1650 namanya dirubah menjadi Statuta van Batavia (Statuta Betawi) dan diberlakukan untuk seluruh wilayah kekuasaan V.O.C.

Setelah itu Pelakat-Pelakat yang baru masih terus bermunculan. Karena kelalaian staf-staf V.O.C menertibkan sejumlah Pelakat yang muncul kemudian, akhirnya pada tahun 1700 terjadi kekacauan sejumlah Pelakat yang muncul setelah 1642. Baru kemudian pada tahun 1766 sejumlah Pelakat setelah tahun 1642 selesai dihimpun dan disusun oleh Oppercoopman Crean dengan nama Nieuw Statuten van Batavia (Statuta Batavia Baru), tapi pengesahannya ditolak oleh Heeren Zeventein di negeri Belanda. Walaupun demikian dalam praktik pengadilan di nusantara Statuta Batavia Baru itu tetap berlaku sebagai peraturan resmi.

Himpunan peraturan yang dibuat oleh V.O.C itu semuanya mencakup hukum privat dan hukum pidana. Untuk hukum privat terus berlaku sampai diberlakukannya kodifikasi hukum privat bagi orang Eropah tahun 1848. Adapun untuk peraturan pidananya berlaku terus sampai diberlakukannya Wetboek van Strafrecht voor de Eropeanen tahun 1866 tanggal 1 Januari 1867 (Stb. 1866 nomor 55) bagi orang Eropah. Sedangkan bagi bangsa Indonesia asli dan Timur Asing berlaku terus sampai diberlakukannya Wetboek van Strafrecht tanggal 1 Januari 1873 (Stb. 1872 nomor 85).

Kitab khusus hukum pidana tersebut, keduanya merupakan saduran dari Code Penal Prancis yang disebut juga dengan Code Penal Napoleon yang telah berlaku di negeri Belanda sejak tahun 1810. Jelasnya Wetboek van Strafrecht voor de Eropeanen 1866 berdasarkan azas konkordansi tetap memberlakukan Code Penal Prancis dengan mengadakan perubahan dan penyesuaian seperlunya. Sedangkan Wetboek van Strafrecht 1872 meniru Wetboek van Strafrecht voor de Eropeanen 1866 dengan perubahan dan penyesuaian serta pengecualian seperlunya.

Dengan demikian di negeri Belanda pada saat itu terjadi praktek Dualisme Hukum, khususnya menyangkut kepidanaan, yaitu di samping tetap diberlakukannya Code Penal Prancis, juga diberlakukan pula Wetboek van Strafrecht voor de Eropeanen 1866. 
Supremasi Hukum Pidana di Indonesia; Bunyana Sholihin

Sehingga kedua aturan pidana dari kedua Kitab Undang-Undang Hukum Pidana itu semuanya berlaku bagi bangsa Belanda di negeri asalnya. Atas dasar azas konkordansi kedua norma aturan pidana tersebut berlaku juga bagi bangsa Belanda yang ada di Indonesia.

Di nusantara berdasarkan azas konkordansi terjadi pula pengaruh yang sama, yaitu terjadi praktek Dualisme Hukum. Bagi bangsa Indonesia asli di samping berlaku Hukum Adat juga berlaku Wetboek van Strafrecht 1872. Sedangkan bagi bangsa Timur Asing (Cina, Arab dan India), di samping berlaku hukum asal masing-masing bangsa berlaku pula hukum adat setempat yang dianut di nusantara dan Wetboek van Strafrecht 1872.

Perkembangan selanjutnya, menjelang priode akhir abad ke 19 mulai dirasakan perlunya unifikasi hukum pidana. Maka pada tahun 1881 pemerintah Belanda mengadakan kodifikasi hukum pidana baru, yaitu Wetboek van Strafrecht 1881 (Stb. 1881 nomor 35) dan diberlakukan secara nasional mulai 1 September 1886 serta sekaligus menggantikan Code Penal Prancis - Wetboek van Strafrecht voor de Eropeanen 1866 dan Wetboek van Strafrecht 1872. Sejak diberlakukannya Wetboek van Strafrecht 1881 itu tidak lagi terdapat praktek dualisme Hukum Pidana di negeri Belanda. Karena sejak saat itu hukum pidana yang berlaku di negeri Belanda tidak ada lain lagi kecuali Wetboek van Strafrecht 1881. Jadi mulai 1 September 1886 di negeri Belanda sudah melakukan unifikasi hukum pidana.

Untuk upaya unifikasi hukum pidana yang berlaku di wilayah jajahan Belanda (Indonesia sekarang) baru diadakan kodifikasi Kitab Undang-Undang Hukum Pidana baru berdasarkan pengumuman raja Belanda tanggal 15 Oktober 1915, sehingga terbentuklah Kitab Undang-Undang Hukum Pidana khusus untuk wilayah jajahan (Indonesia) yang disebut Wetboek van Strafrecht voor Nederlandsch-Indie 1915 yang merupakan perubahan dan penyesuaian dari Wetboek van Strafrecht 1881.

Kemudian berdasarkan firman raja Belanda (Invoerings-verordening) tanggal 4 Mei 1917 (Stb. 1917 nomor 497) Wetboek van Strafrecht voor Nederlandsch-Indie 1915 dinyatakan berlaku di seluruh wilayah nusantara mulai 1 Januari 1918 sekaligus menggantikan Wetboek van Strafrecht voor de Eropeanen 1866 dan Wetboek van Strafrecht 1872.

Dengan demikian sejak tanggal 1 Januari 1918 secara resmi terlaksana unifikasi hukum pidana di Indonesia. Dalam artian sejak tanggal tersebut telah berlaku satu Kitab Undang-Undang Hukum Pidana untuk seluruh penduduk di seluruh wilayah nusantara.

\section{c. Tahapan Zaman pendudukan Jepang}

Pada tanggal 8 Maret 1942 Jepang memasuki dan menduduki wilayah nusantara setelah mengalahkan pasukan Sekutu. Sejak saat itu pasukan Jepang mengambil alih kedudukan negara anggota Sekutu di antaranya Belanda di Indonesia sebagai penjajah.

Dengan masuknya tentara Jepang menguasai wilayah pendudukan kolonial Belanda di Indonesia berarti sekaligus menggantikan penjajahan Belanda di Indonesia. Penjajahan bangsa Jepang di Indonesia ini mempunyai pengaruh yang sangat besar terhadap dinamika aturan hukum pidana di Indonesia. Demi kepentingan kekuasaan dan pemerintahannya dalam beberapa hal tertentu pemerintahan Jepang 
UNISIA, Vol. XXXI No. 69 September 2008

mengeluarkan maklumat yang memuat ketentuan pidana dan memberlakukannya di seluruh wilayah pendudukannya.

Namun demikian sepanjang sejarah pendudukan Jepang di Indonesia tidak pernah mencabut berlakunya Wetboek van Strafrecht voor Nederlandsch-Indie 1915. Dengan demikian sepanjang sejarah pendudukan Jepang hukum pidana yang berlaku di Indonesia terdapat dua aturan pidana secara bersamaan, yaitu aturan pidana yang dikeluarkan oleh pemerintahan Jepang dan aturan pidana peninggalan pemerintahan kolonial Belanda Wetboek van Strafrecht voor Nederlandsch-Indie 1915. Jadi selama Jepang berkuasa di Indonesia kembali berlaku Dualisme Hukum Pidana.

\section{d. Tahapan zaman Republik}

Bangsa Indonesia baru dapat keluar dari cengkraman penjajah dan mencapai kemerdekaannya pada hari Jum'at tanggal 17 Agustus 1945, yaitu sejak dibacakannya Naskah Proklamasi Kemerdekaan Bangsa Indonesia oleh wakil bangsa Indonesia Soekarno-Hatta, yang kemudian menjadi presiden dan wakil presiden Republik Indinesia pertama.

Selanjutnya pada tanggal 18 Agustus 1945 langsung diberlakukan Undang-Undang Dasar 1945 sebagai Sumber Hukum Tertinggi dalam tertib hukum Negara Kesatuan Republik Indonesia. Dalam pasal II Aturan Peralihan UUD 1945 dinyatakan, bahwa segala lembaga negara dan peraturan hukum yang ada pada waktu itu (Wetboek van Strafrecht voor nederlandsch-Indie 1915 dan ketentua-ketentuan pidana pemerintahan Jepang) masih tetap berlaku selama belum diganti dengan yang baru menurut UUD 1945 itu sendiri. Dengan demikian sampai dengan 18 Agustus 1945, dualisme hukum pidana kembali berlaku karena Aturan Pidana
Pemerintahan Jepang masih berlaku terus di Indonesia.

Selanjutnya pemerintah Republik Indonesia merasa dan menyadari perlu diupayakannya kembali unifikasi hukum pidana. Maka dalam keadaan darurat selanjutnya pada tanggal 26 Pebruari 1946 dikeluarkan Undang-Undang nomor 1 tahun 1946 termuat dalam Berita Republik Indonesia II nomor 9 tentang hukum pidana yang berlaku di Republik Indonesia yang isinya hal-hal berikut:

1) Mencabut berlakunya semua peraturan hukum pidana yang dikeluarkan oleh pemerintah Jepang.

2) Mencabut semua peraturan hukum pidana yang dikeluarkan oleh Panglima Tertinggi Balatentara Hindia Belanda.

3) Peraturan-peraturan hukum pidana yang masih tetap dan terus berlaku di Republik Indonesia adalah peraturan hukum pidana yang dikeluarkan oleh pemerintah Hindia Belanda tahun 1915.

4) Merobah kata Nederlandsche-Indie atau Nederlandschen-Indisch dalam peraturan hukum pidana yang masih berlaku menjadi kata Indonesia atau Indoneseschen.

5) Merubah nama Wetboek van Strafrecht voor Nederlandsch-Indie menjadi Wetboek van Strafrecht dan selanjutnya diterjemahkan menjadi Kitab Undang-Undang Hukum Pidana.

6) Semua kata Nederlandsch Ondordaan dalam Kitab Undang-Undang Hukum Pidana diganti dengan Warga Negara Indonesia.

7) Mencabut atau merubah beberapa pasal dari Kitab Undang-Undang Hukum pidana.

8) Memuat beberapa tindak pidana baru.

9) Menetapkan bahwa Undang-Undang ini berlaku buat pulau Jawa dan Madura mulai tanggal 26 Pebruari 1946. 
Supremasi Hukum Pidana di Indonesia; Bunyana Sholihin

\section{Pembahasan}

Berdasarkan Undang-Undang Darurat Nomor 1 tahun 1946 dimaksud, berarti Undang-Undang Hukum Pidana di Indonesia mulai tanggal 26 Pebruari 1946 baru berlaku khusus untuk Jawa dan Madura. Selanjutnya pada tanggal 8 Agustus 1946 berdasarkan Peraturan pemerintah Republik Indonesia Nomor 8 tahun 1946 dimuat dalam Berita II Nomor 20-21., Kitab Undang-Undang Hukum Pidana tersebut diberlakukan pula untuk seluruh Sumatra. Tetapi ketika itu pemerintah Federal Hindia Belanda telah memasuki dan menguasai beberapa daerah Republik dan memberlakukan Kitab Undang-Undang Hukum Pidana tersendiri untuk daerah-daerah yang dikuasai.

Dari itu semua ternyata upaya unifikasi hukum pidana bagi Negara Kesatuan Republik Indonesia selama itu masih belum berwujud menjadi kenyataan. Sejak Proklamasi Kemerdekaan belum pernah terlaksana berlakunya Undang-Undang Hukum Pidana di seluruh wilayah Negara Kesatuan Republik Indonesia. Kondisi Hukum Pidana seperti ini berlanjut terus sepanjang kedaulatan Republik Indonesia Serikat (27 Desember 1946 - Juli 1950) dan sepanjang Negara Kesatuan Republik Indonesia menganut Undang-Undang Dasar Sementara 1950 sampai dikeluarkannya Undang-Undang Nomor 73 tahun 1958 tanggal 29 September 1958 yang menyatakan berlakunya Undang-Undang Republik Indonesia No. 1 tahun 1946 tentang Peraturan Hukum Pidana untuk seluruh wilayah Republik Indonesia dan perubahannya.

Berdasarkan data sejarah tersebut, jadi dapat ditegaskan bahwa tenggelamnya unifikasi Hukum Pidana di Indonesia akibat masuknya pendudukan bangsa Jepang di Indonesia. Baru bisa muncul kembali mulai tanggal 29 September 1958 setelah dikeluarkannya Undang-Undang Nomor 73 tahun 1958. Sejak tanggal tersebut hingga sekarang ini Hukum Pidana yang berlaku bagi seluruh penduduk di seluruh wilayah kedaulatan Negara Kesatuan Republik Indonesia hanyalah satu, yaitu Kitab UndangUndang Hukum Pidana terjemahan dari Wetboek van Strafrecht voor NederlandschIndie 1915 yang telah berlaku di Indonesia sejak tanggal 1 Januari 1918 dengan sebanyak mungkin diadakan perubahan dan penyesuaian dengan keadaan Negara Kesatuan Republik Indonesia yang merdeka.

Tidak lama setelah Kitab UndangUndang Hukum Pidana warisan kolonial Belanda itu resmi berlaku secara unifikasi, diikuti dengan berkembangnya perasaan hukum dan keadilan bangsa Indonesia serta munculnya tuntutan pembinaan dan pengembangan Negara Kesatuan Republik Indonesia dalam segala bidang, sehingga segera dirasakan bahwa aturan pidana peninggalan kolonial Belanda itu tidak sesuai lagi dan perlu diadakan upaya pembaharuannya.

Hukum pidana warisan kolonial Belanda ini terbukti hanya sesuai untuk diberlakukan di Indonesia pada masa bangsa Indonesia masih di bawah jajahan Belanda. Karena pemerintahan kolonial Belanda memang dengan penuh kesengajaan menyusun materi hukum pidana dimaksud (Wetboek van Strafrecnt voor Nederlandsch Indie 1915) khusus untuk diberlakukan bagi bangsa jajahan di wilayah jajahan Belanda. Dengan kata lain substansi materi hukum dari aturan pidana peninggalan Belanda itu adalah materi hukum pidana untuk konsumsi bangsa terjajah.

Maka tidak mengherankan kalau praktek pelaksanaan hukum pidana Indone- 
UNISIA, Vol. XXXI No. 69 September 2008

sia yang diberlakukan sampai sekarang ini masih dirasakan bukan sebagai acuan bertindak dan berbuat serta menegakkan keadilan bagi segenap bangsa Indonesia, namun hukum sebagai alat legitimasi demi kepentingan penguasa yang korup dan otoriter, hukum sebagai alat untuk mencapai kepentingan penguasa serta segelintir orang-orang dekat dan keroco-keroconya saja sehingga menimbulkan ketidak-adilan yang menyengsarakan rakyat pada umumnya. Hal ini karena nilai keadilan yang diterapkan berbeda dengan nilai keadilan yang menjiwai jiwa hukum yang dianut oleh anak bangsa Indonesia yang merdeka, hingga masyarakat bangsa pada umumnya merasa, bahwa aturan hukum itu tidak ada lagi dan hukum itu bukanlah sesuatu hal yang patut diikuti karena hukum itu dirasakan merampas hak kemerdekaan bangsa.

Sehubungan dengan itu melalui Departemen Kehakiman Pemerintah Republik Indonesia membentuk Lembaga Hukum Nasional (LHN) yang kemudian di masa Orde Baru berkembang menjadi Badan Pembinaan Hukum Nasional (BPHN) dengan kewenangan dan tugasnya adalah menyusun kodifikasi Hukum Pidana Nasional yang sesuai dengan kesadaran dan kebutuhan hukum bangsa Indonesia yang merdeka, sekaligus sebagai pengganti Kitab Undang-Undang Hukum Pidana warisan kolonial Belanda yang dirasa tidak sesuai lagi dengan jiwa hukum bangsa Indonesia yang merdeka.

Lembaga hukum yang dibentuk pemerintah tersebut, dalam rangka realisasi tujuan dan tugasnya telah berulang kali melaksanakan penelitian, seminar dan simposium hukum pidana bekerjasama dengan berbagai Perguruan Tinggi Negeri dan Swasta, organisasi profesi yang melibatkan para pakar hukum, budayawan dan ulama. Di-antaranya telah diadakannya Seminar Hukum Nasional yang dilaksanakan tahun 1963 dengan rumusan hasil yang menyarankan agar segera diujudkan kodifikasi Hukum Pidana Nasional yang dinamis dan progressif serta sesuai dengan jiwa hukum bangsa Indonesia. Namun hingga sekarang hasilnya baru berupa tumpukan Laporan Seminar yang masih perlu diolah menjadi Bahan Rancangan Undang-Undang untuk kemudian dapat diterima dan diberlakukan sebagai Undang-undang Hukum Pidana Nasional setelah melalui proses yang masih memerlukan waktu yang cukup panjang.

Karena lambanya kinerja Badan Pembinaan Hukum Nasional ini, semakin membuat masyarakat putus asa dan hilang kepercayaan akan kesungguhan pemerintah mewujudkan Undang-undang Hukum Pidana Nasional yang sesuai dengan jiwa hukum bangsa. Keberadaan penguasa seakan tampak sekedar memanfaatkan kesempatan hidup berfoya-foya di atas kekacauan dan kesengsaraan rakyatnya, mempertahankan menempatkan hukum sekedar sebagai alat legetimasi untuk memenuhi kebutuhan dan mencapai kepentingan penguasa serta segelintir orang-orang dekatnya. Oleh karena itu, kekecewaan masyarakat tidak terbendung lagi akhirnya meluap menimbulkan berbagai tindakan kekerasan, sebagaimana diberitakan dalam sejumlah mess-media. Di antaranya seperti peristiwa-peristiwa dibawah ini:

Seorang dari tiga kawanan pencuri yang gagal melakukan pencurian Sepeda motor RX King milik seorang warga Desa Srikuncoro Kecamatan Pembantu Semaka, Wonosobo Kabupaten Tanggamus Propinsi Lampung, ahad 13 Agustus 2000, tewas dibantai massa. 
Sumardi seorang pedagang keliling karena tuduhan mencuri ayam hari Selasa dinihari, 15 Agustus 2000, di desa Padang Jaya Kecamatan majenang kabupaten Cilacap Jawa Tengah telah menjadi korban pembakaran massa.

Kasatlak Trantib Jakarta Barat, bersimbah darah akibat sabetan golok massa yang mempertahankan rumah mereka di atas lahan milik Perum Perumnas Unit III Cengkareng dari pembongkaran petugas.

Memperhatikan berbagai perkembangan modus tindak kekerasan tersebut telah semakin membuktikan, bahwa materi hukum pidana peninggalan kolonial yang sampai sekarang masih berlaku di Indonesia itu sudah semakin dirasakan tidak sesuai lagi dengan jiwa hukum dan budaya hukum bangsa Indonesia yang merdeka. Oleh karena itu Supremasi hukum pidana di Indonesia tidak bisa lagi dapat diharapkan seutuhnya terwujud selama masih mempertahankan berlakunya Undangundang Hukum Pidana terjemahan dengan segala perubahan dan penyesuaiannya dari Wetboek van Strafrecnt voor Nederlandsch Indie 1915. Dengan demikian untuk tegak dan berlakunya Supremasi Hukum Pidana di Indonesia Undang-undang Hukum Pidana Indonesia terjemahan dari Wetboek van Strafrecnt voor Nederlandsch Indie 1915 dengan segala perubahan dan penyesuaiannya itu sudah perlu segera diganti dengan sistem hukum yang sesuai dengan nilai dan budaya hukum yang dianut oleh bangsa Indonesia yang merdeka.

Indonesia adalah Negara Hukum karena UUD 1945 sebagai landasar dasar kemerdekaan bangsa Indonesia menganut Azas Negara Hukum. Negara hukum itu sendiri adalah negara yang tegak dan berdiri di atas hukum dan senantiasa menjunjung tinggi hukum yang menjamin keadilan bagi warga negeranya sebagaimana ditegaskan dalam pasal 27 UUD 1945 itu sendiri. Berdasarkan kondisi Indonesia sebagai Negara Hukum sebagaimana dimaksudkan, sudah menjadi suatu keharusan Supremasi Hukum Pidana di Indonesia berdiri tegak dan berjalan dalam praktek kehidupan bangsanya.

Untuk menjawab tuntutan pembaharuan hukum pidana Indonesia yang dinamis, progresif dan sesuai dengan jiwa hukum bangsa itu, maka sudah semestinya para ahli hukum Indonesia mulai menggali baik materi hukum maupun nilai-nilai hukum yang sesuai dan dianut oleh umumnya bangsa Indonesia yang merdeka,sehingga secara substantif materi hukum yang diberlakukan sesuai dengan jiwa dan budaya hukum bangsa sebagai subyek dan obyek perundang-undangan hukum pidana yang akan dihasilkan.

Berdasarkan fakta sebagai realita, delapan puluh lima persen bangsa Indonesia beraliran dan berfaham hukum AsySyafi'i. Dengan demikian jiwa hukum dan budaya hukum bangsa Indonesia terakomulasi dalam lingkup hukum Syari'ah beraliran mazhab hukum Asy-Syafi'i i.

\section{Penutup}

Sebagai hasil analisa terhadap segala temuan dalam bahasan terdahulu maka dapat ditawarkan kesimpulan sebagai jawaban terhadap permasalahannya sbb:

1. Hukum pidana yang berlaku di Indonesia hingga saat ini masih merupakan hukum pidana pemerintahan kolonial Belanda yang khusus diberlakukan untuk bangsa jajahan Belanda walupun telah diadakan perubahan dan perbaikan disana-sini. 
UNISIA, Vol. XXXI No. 69 September 2008

2. Hukum pidana kolonial Belanda tidak sesuai dengan jiwa dan semangat keadilan bangsa Indonesia yang mayoritas berjiwa dan semangat hukum syari'ah.

3. Supremasi hukum pidana tidak bisa diharapkan seutuhnya terwujud di Indonesia selama masih mempertahankan berlakunya Undangundang Hukum Pidana terjemahan dengan segala perubahan dan penyesuaiaannya dari Wetboek van Strafrecnt voor Nederlandsch Indie 1915.

Sebagai saran untuk dapat tegaknya Supemasi Hukum Pidana di Indonesia idealnya hukum pidana yang hendaknya diberlakukan di Indonesia adalah aturan pidana yang menjiwai rasa kebenaran dan keadilan bangsa Indonesia, yaitu aturan pidana syari'ah yang dianut dan diyakini oleh mayoritas bangsa Indonesia.

\section{Daftar Pustaka}

B.P.H.N., 1975, Simposium Pengaruh Kebudayaan/Agama Terhadap Hukum Pidana,Bandung: Bina Cipta.

Hadikusuma, Hilman, 1989. Masyarakat dan Adat Budaya Lampung, Bandung: Penerbit Mandar Maju.

Halim, A. Ridwan,1983. Hukum Pidana Dalam Tanya Jawab, Jakarta:Ghalia Indonesia.
John M. Echols, 1986, Kamus Inggris-Indonesia, Jakarta:Gramedia-Indonesia, Cet. XIV.

Kusnardi, et all.1980, Pengantar Hukum Tata Negara Indonesia, Jakrta:Fakultas Hukum U.I.

Majalah Hukum dan Keadilan, Laporan Simposium Pembaharuan Hukum Nasional, PERADIN, No. Edisi 15., Jakarta, 1980.

Moeljatno,1978. Kitab Undang-Undang Hukum Pidana, t.t., Yogyakarta: Liberty.

Prodjodikoro, Wirjono,1979. Azas-Azas Hukum Pidana di Indonesia, Bandung: Eresco.

Poerwadarminta, WJS.1986. Kamus Umum Bahasa Indonesia, Jakarta: Balai Pustaka.

Satjipto Rahardjo, 1982. Ilmu Hukum, Bandung: Alumni.

Utrecht,1983. Pengantar Dalam Hukum Pidana, Jakarta:Ikhtiar Baru. 